\title{
A Comparison of Actual and Expected Selection Responses from Selection Indices for Desired Gains in Layer Chicken Lines
}

\author{
Fumio MUKAI, Kenji OYAMA ${ }^{1)}$, \\ Soichi TSUJI and Toru MIYATA ${ }^{2)}$ \\ Faculty of Agriculture, Kobe University, Nada-ku, Kobe-shi 657 \\ ${ }^{1)}$ Graduate School of Science and Technology, Kobe University, \\ Nada-ku, Kobe-shi 657 \\ ${ }^{2)}$ National Livestock Improvement Center, Okazaki Station, \\ Okazaki-shi 444-2l
}

(Received May 27, 1996)

\begin{abstract}
In Okazaki station of National Livestock Improvement Center, selection index for desired gains based on the assumed parameters has been used to improve layer chicken. The same indices were applied on three lines from 1989 to 1994. Pre-specified restrictions as objective were no change on egg weight at 252 days of age ( $E W)$ and body weight at 256 days of age (BW), $5 \%$ increase of egg production efficiency from first egg to 280 days of age in all lines, and more five days reduction of age at first egg (SM) was aimed in one line. The EW, BW, SM and egg production efficiency between 169-280 days were included in the index as selection criteria. In this study, expected theoretical responses from the index were compared with actual responses obtained by the regression of average predicted breeding values by birth year multiplied by number of generation selected. Breeding values of five traits were predicted with multiple-trait BLUP under animal models using (co) variances estimated with REML. Directions of the actual responses for the traits except $\mathrm{BW}$ agreed well with those of expected theoretical responses in all lines. Disagreement found in BW was caused by the difference between assumed genetic correlations and REML ones. The amount of responses was less than theoretically expected and differed across lines reflecting the discrepancy between genetic parameters assumed and REML estimates in each line. The results indicate that more reliable genetic parameters for a line under question, the so-called REML estimates, should be used in order to attain pre-specified objectives.

Anim. Sci. Technol. (Jpn.) 67 (11) : 941-948, 1996

Key words : Desired gain index, Breeding objective, Selection responses, Breeding value, Layer lines
\end{abstract}

In animal breeding, multiple traits are often aimed to be improvement. Since $\mathrm{Hazel}^{2)}$ has proposed the selection index method for use in animal populations in 1943, various types of selection indices have been developed towards the achievement of different objectives $^{4-6,8,10,15,16)}$. Generally, for constructing the index, economic weights are required on the objective traits. However, in practice, their estimation may be difficult because they fluctuate depending on demand and genetic level of a population. On the other hand, sclection index for desired gains by Yamada et al. ${ }^{16)}$, proposed as the index with restriction for pre- 
determined genetic changes in individual traits, requires no economic weights. In Okazaki station of the National Livestock Improvement Center, the desired gain index has been used to improve layer chicken lines for the last decade. However there is no reports on efficiency of the desired gain index because of some difficulties assessing genetic trends for the traits in practical layer selection without control line. A recent development of Best Linear Unbiased Prediction (BLUP) ${ }^{3 \gamma}$ under an animal model makes it possible to trace the genetic and environmental changes due to selection without control line $\mathrm{e}^{13)}$. In addition, genetic parameters used for constructing the index in Okazaki station were referred from literature. A discrepancy of assumed parameters from true ones for a line under question must decrease selection response expected by the index.

The objective of this study was to predict genetic trends with BLUP under multiple-trait animal model using genetic parameters estimated with Restricted Maximum Likelihood $(\mathrm{REML})^{9)}$ procedure in each layer line and compare them with expected selection responses from the desired gain index derived by genetic parameters assumed at the station.

\section{Materials and Methods}

Data from National Livestock Improvement Center, Okazaki station were used in this study. They consisted of White Leghorn line (E 1), recessive White Rock line (L 17) and Rhode Island Red line (Y 8) which were selected between 1989 and 1994. The traits measured were egg weight at 252 days of age (EW, g), body weight at 256 days of age $(\mathrm{BW}, \mathrm{kg})$, age at first egg (SM, days), and egg production efficiencies A (EPA, \%) and B (EPB, \%) recorded between 169-280 days and from first egg to 280 days, respectively. Basic statistics for the traits were reported by Danbaro et al. ${ }^{1)}$.

Number of fully pedigreed chickens with records, effective population size, selected fractions and standardized selection differential for females in three lines are shown in Table 1. Selection for females was on an index for desired gains. Desircd gains $(\mathbf{q})$ to each line are given in Table 5 . In all lines, no genetic changes on $\mathrm{BW}$ and $\mathrm{EW}$, no weight on EPA, and $5 \%$ increase of $\mathrm{EPB}$ were pre-determined as restriction. A reduction of five days in $\mathrm{SM}$ was aimed only in Y 8 . Selection was continued for five generations. Selected fractions fluctuated from generation to generation with average of $26 \%$ to $19 \%$, corresponding to the

Table 1. Number of chickens with records (No.), effective population size $\left(\mathrm{N}_{\mathrm{e}}\right)^{2}$, selected fraction (p) and standardized selection intensity $(i)^{\mathrm{b}}$ in layer lines

\begin{tabular}{|c|c|c|c|c|c|c|c|c|c|c|c|c|}
\hline \multirow{2}{*}{ Year } & \multicolumn{4}{|c|}{ Line E 1} & \multicolumn{4}{|c|}{ Line L 17} & \multicolumn{4}{|c|}{ Line $\mathrm{Y} 8$} \\
\hline & No. & $\mathrm{N}_{\mathrm{e}}$ & $p(\%)$ & $i$ & No. & $N_{e}$ & $\mathrm{p}(\%)$ & $i$ & No. & $\mathrm{N}_{\mathrm{a}}$ & $\mathrm{p}(\%)$ & $i$ \\
\hline 1989 & 405 & 43 & 21 & 0.69 & 421 & 42 & 5 & -0.30 & 318 & 34 & 33 & 0.09 \\
\hline 1990 & 405 & 75 & 31 & 0.57 & 431 & 65 & 3 & 0.20 & 354 & 67 & 27 & 0.70 \\
\hline 1991 & 564 & 76 & 24 & 0.55 & 466 & 104 & 41 & 0.39 & 632 & 63 & 20 & 0.59 \\
\hline 1992 & 373 & 96 & 37 & 0.57 & 907 & 98 & 15 & 0.51 & 329 & 93 & 31 & 0.54 \\
\hline 1993 & 628 & 96 & 19 & 0.66 & 618 & 140 & 27 & 0.48 & 742 & 117 & 21 & 0.64 \\
\hline 1994 & 465 & - & - & - & 592 & - & - & - & 620 & - & - & - \\
\hline Mean & 473 & $71^{*}$ & 26 & $0.61^{*}$ & 573 & $73^{*}$ & 19 & $0.26^{*}$ & 499 & $66^{*}$ & 25 & $0.51^{*}$ \\
\hline
\end{tabular}

${ }^{a} N_{e}=4 N_{m} N_{f} /\left(N_{m}+N_{f}\right), N_{m}$ : Number of sires, $N_{f}$ : Number of dams.

${ }^{b}$ Calculating by standardized selection difference between average index scores of selected and all chickens.

* Harmonic mean. 
intensity of 1.25 to 1.43 . The average standardized selection intensities measured from the index score differentials in females were considerably less than those expected from selected fractions since for practical reasons the color and quality of shell were also considered in final selection in addition to the loss due to diseases and inevitable accidents. For replacement males, two males were chosen from each selected full-sib family and one male was finally selected based on phenotype related to physical soundness. However numbers of candidate families and of males in each family were not clear. Therefore exact selection intensity on the score was unknown. One sire was mated with between 5 and 8 dams with full attention to the avoidance of inbreeding.

REML gives more reliable estimates of variance and covariance components in the base population if all records used in selection and pedigree information from the start of selection are available ${ }^{14)}$. In this study, variance and covariance components were cited from a paper by Danbaro et al. ${ }^{1}$ in which the multiple -trait REML under animal models was applied on each selected line.

Breeding values of the traits were predicted with BLUP under multiple-trait animal models ${ }^{3)}$. In the linear mixed models, year and house were considered as fixed effects, and inbreeding coefficient of individual was included as a covariate. Random effects were animals (breeding values) and residuals. Genetic changes, namely trends, were expressed as regression coefficients of average predicted breeding values (PBV) by birth year on generation.

The desired gain indices actually used in the station $\left(I_{A}\right)$ were derived from an usual simple manner ${ }^{16)}$ as $\mathbf{b}_{\mathrm{A}}=\mathbf{G}_{\mathrm{A}}{ }^{-1} \mathbf{q}$, based on assumed genetic parameters given in Tables 2 and 3 . To accomplish objective q, EW, BW, SM and EPA were used as selection criteria. Another indices $\left(I_{R}\right)$ were examined by using REML esti. mates; $\mathbf{b}_{R}=\mathbf{G}_{\mathrm{R}}^{-1} \mathbf{q}$. The $\mathbf{b}_{\mathrm{A}}$ and $\mathbf{b}_{\mathrm{R}}$ stand for weighting coefficient vectors of the indices, and $\mathbf{G}_{\mathrm{A}}$ and $\mathbf{G}_{\mathrm{R}}$ for genetic variance and covariance matrices between the traits of selection criteria and objective where subscripts $A$ and $R$ represent $\mathbf{b}$ and $\mathbf{G}$ are derived from assumed parameters in the station and REML estimates, respectively.

It must be noticed that $\mathbf{q}$ expresses the gains attained after $\sigma_{1_{\mathrm{A}}} / i_{\mathrm{A}}$ generations only when parameters used are true and selection succeeds according to plan. The $\sigma_{\mathrm{I}_{\mathrm{A}}}$ stands for standard deviation of $\mathrm{I}_{\mathrm{A}}$ and $i_{\mathrm{A}}$ for the actual selection intensity calculated by selection differential of the index scores (Table 1). However actual

Table 2. Comparison of heritabilities, and genetic and residual variance components between assumed at the station and estimated by REML

\begin{tabular}{|c|c|c|c|c|c|c|c|c|c|c|c|c|}
\hline \multirow{3}{*}{ Traits } & \multicolumn{4}{|c|}{ Heritabilities } & \multicolumn{4}{|c|}{ Genetic variances } & \multicolumn{4}{|c|}{ Residual variances } \\
\hline & \multirow[t]{2}{*}{ Assumed } & \multicolumn{3}{|c|}{ REML } & \multirow[t]{2}{*}{ Assumed } & \multicolumn{3}{|c|}{ REML } & \multirow[t]{2}{*}{ Assumed } & \multicolumn{3}{|c|}{ REML } \\
\hline & & E 1 & L 17 & Y 8 & & E 1 & L 17 & Y 8 & & E 1 & $\mathrm{~L} 17$ & Y 8 \\
\hline $\mathrm{EW}(\mathrm{g})$ & 0.50 & 0.51 & 0.53 & 0.59 & 8.00 & 8.58 & 8.88 & 10.98 & 8.00 & 8.24 & 7.74 & 7. 60 \\
\hline $\mathrm{BW}(\mathrm{kg})$ & 0.50 & 0.56 & 0.51 & 0.52 & 0.013 & 0.010 & 0.016 & 0.017 & 0.013 & 0.008 & 0.015 & 0.015 \\
\hline SM(days) & 0.40 & 0.45 & 0.41 & 0.35 & 67.60 & 68.86 & 59.19 & 94.75 & 101.40 & 83.15 & 84.41 & 174.80 \\
\hline $\mathrm{EPA}(\%)$ & 0.15 & 0.13 & 0.19 & 0.15 & 25.35 & 11.70 & 13. 49 & 18.24 & 143.65 & 74.42 & 58.79 & 103. 80 \\
\hline $\mathrm{EPB}(\%)$ & 0.10 & 0.20 & 0.22 & 0.27 & 10.00 & 18.49 & 16.62 & 38.04 & 90.00 & 75.15 & 59.78 & 103.22 \\
\hline
\end{tabular}

$\mathrm{EW}=\mathrm{Egg}$ weight measured at 252 days, $\mathrm{BW}=$ Body weight at 256 days, $\mathrm{SM}=$ Age at first egg,

$\mathrm{EPA}=\mathrm{Egg}$ production efficiency recorded between $169-280$ days, $\mathrm{EPB}=\mathrm{Egg}$ production effciency recorded from first egg to 280 days. 
and expected responses may deviate from $\mathbf{q}$ due to the bias of genetic parameters and selection process from intended ones. Selection responses in five traits were examined as following methods. Expected responses $\left(g_{e}\right)$ based on $\mathrm{I}_{\mathrm{A}}$ were estimated as $\mathbf{g}_{\mathrm{e}}=\mathbf{G}_{\mathrm{R}} \mathbf{b}_{\mathrm{A}}$. The $\mathbf{g}_{\mathrm{e}}$ is correlated response, which may be expected after $\sigma_{\mathrm{I}_{\mathrm{A}}} / i_{\mathrm{A}}$ generations if selection pressure based on $I_{A}$ acts on the variance and covariance structure estimated by REML in the ideal condition, because $G_{R}$ reflects the real genetic structure of the base in each line well rather than $\mathbf{G}_{\mathrm{A}}$. The actual responses obtained from index selection $\left(\mathbf{g}_{\mathrm{a}}\right)$ were calculated by regression coefficients of average PBV on generation multiplied by number of generations selected $(N G=5)$. Theoretical responses $\left(g_{t}\right)$ were estimated as follows; $\mathbf{g}_{\mathrm{t}}=\mathbf{g}_{\mathrm{e}} \times \frac{\mathrm{NG}}{\sqrt{\mathbf{b}^{\prime}{ }_{\mathrm{A}} \mathbf{P}_{\mathrm{R}} \mathbf{b}_{\mathrm{A}}} / i_{\mathrm{A}}}$ in which $\mathbf{P}_{R}$ stands for phenotypic variance and covariance matrix by REML. The $\mathbf{g}_{\mathfrak{t}}$ means the response expected under the actual selection intensity within five generation in the planned condition.

\section{Results and Discussion}

Assumed heritabilities of EW, BW, SM and EPA did not differ largely from those by REML, although assumed heritabilities of EPB were relatively smaller than those by REML, considering their sizes as given in Table 2. On the other hand, large differences between variance components were found. Especially both genetic and residual components in EPA were assumed larger than those by REML. The over assumption may result in smaller responses in EPA and other correlated traits than expected.

As the genetic correlations shown in Table 3 , different correlations $(-0.15$ vs. -0.6$)$ were assumed between EW and egg production efficiencies (EPA and EPB). However, for REML estimates, large difference was not found within each line, but considerable differences existed across lines. Also no genetic relationships were assumed between $\mathrm{BW}$ and EPA or EPB, but low correlations were suggested. Degree of discrepancy was depending on the combination of the traits and lines. Especially, large differences were found

Table 3. Comparison of genetic correlations between assumed at the station and estimated by REML

\begin{tabular}{|c|c|c|c|c|}
\hline \multirow{2}{*}{$\begin{array}{l}\text { Combination } \\
\text { of traits }\end{array}$} & \multirow{2}{*}{ Assumed } & \multicolumn{3}{|c|}{ REML } \\
\hline & & E 1 & L 17 & Y 8 \\
\hline \multicolumn{5}{|l|}{ EW : } \\
\hline BW & 0.30 & 0.33 & 0.28 & 0.30 \\
\hline SM & 0.10 & 0.13 & 0.03 & 0.50 \\
\hline EPA & -0.15 & -0.31 & -0.16 & -0.46 \\
\hline $\mathrm{EPB}$ & -0.60 & -0.18 & -0.13 & -0.52 \\
\hline \multicolumn{5}{|l|}{ BW : } \\
\hline $\mathrm{SM}$ & 0.10 & -0.01 & 0.06 & 0.35 \\
\hline EPA & 0.00 & -0.05 & -0.15 & -0.15 \\
\hline $\mathrm{EPB}$ & 0.00 & 0.04 & -0.10 & 0.10 \\
\hline \multicolumn{5}{|l|}{$\mathrm{SM}$} \\
\hline EPA & -0.30 & -0.47 & -0.23 & -0.81 \\
\hline $\mathrm{EPB}$ & -0.50 & -0.70 & -0.33 & -0.80 \\
\hline \multicolumn{5}{|l|}{ EPA : } \\
\hline EPB & 0.85 & 0.80 & 0.89 & 0.93 \\
\hline
\end{tabular}


in genetic correlations between SM and egg production efficiencies in Y 8.

The weighting coefficients, $\mathbf{b}_{\mathrm{A}}$ and $\mathbf{b}_{\mathrm{R}}$ of desired gain indices derived from two parameter sets are shown in Table 4. The discrepancy may affect correlated selection responses not only in amount but also in direction, as compared with pre-specified objective because the index scores of individuals and their ranking must change according to the weighting coefficients. The coefficients of BW in $\mathrm{L} 17$ and of SM in $Y 8$ have reverse signs, when comparing both indices. Therefore the actual indices would result in more decrease changes in $B W$ in $L 17$ and $S M$ in $Y 8$ rather than prespecified. The index $I_{R}$ in $L 17$ derived from REML estimates indicates that in order to maintain $\mathrm{BW}$ constant, chickens with heavier BW must be scored somew hat higher, provided that REML estimates reflect well the genetic variance and covariance structure of the base in L 17. However, $I_{A}$ used in the station has small but negative weight on $\mathrm{BW}$ so that negative pressure acts on $\mathrm{BW}$ and as a result, chickens with smaller BW would be selected for. Therefore, the discrepancy of weighting coefficients on BW must result in decrease change regardless of restriction to no genetic change. The same phenomena will be expected to happen in SM of Y 8.

A comparison of some kinds of selection responses is shown in Table 5. In lines $\mathbf{E} \mathbf{1}$ and L 17 the same breeding objectives (q) were prespecified. However, the $\mathbf{q}$ and $\mathbf{g}_{\mathrm{e}}$ in two lines differed each other according to the difference between $G_{A}$ and $G_{R}$ in both lines. Increasing trend in EPA and decreasing trend in SM due to selection on $I_{A}$ at the center were favorable in practical layer breeding and rational because no restriction on SM and EPA as objectives. Large amount of expected decrease in $B W$, especially in $L 17$, was caused by the discrepancy between weighting coefficients of $I_{A}$ and $I_{R}$. As the actual responses $\left(\mathbf{g}_{a}\right)$, genetic trends of the traits except $\mathrm{EW}$ in $\mathrm{E} 1$ and $\mathrm{EW}$ and $S M$ in $L 17$ showed significant changes $(\mathrm{P}<$ 0.05). From a qualitative view point, these trends except BW are consistent with the objective and theoretical responses $\left(\mathbf{g}_{\mathrm{t}}\right)$. The amount of responses obtained in EPA and EPB in $\mathrm{L} 17$ was comparable with those of theoretical ones, but not enough in $\mathrm{E} 1$.

In line $Y 8$, the index for reduction of five days in SM may change EW and BW downward rather than expected, because positive large correlations of SM with $\mathrm{EW}$ and $\mathrm{BW}$ were existed in addition to negative large correlation between EW and EPA. All actual responses except EW were consistent in direction with theoretical responses. However, responses attained in SM and EPB were about one half of theoretical ones. Change of BW was not significant but somewhat large. This change may be explained in part by the existence of genetic correlation of 0.35 between SM and $\mathrm{BW}$.

In all lines, selection responses attained in the station except those of body weight were

Table 4. Comparison of weighting coefficients of selection indices for desired gains derived from assumed parameters and REML estmates

\begin{tabular}{lccccc}
\hline \hline Line & Parameters (Index) & EW & BW & SM & EPA \\
\hline E1 & Assumed $\left(I_{\mathrm{A}}\right)$ & 0.1227 & -0.0009 & - & 0.4181 \\
& REML $\left(\mathrm{I}_{\mathrm{R}}\right)$ & 0.1814 & -0.0010 & - & 0.4632 \\
\hline L17 & Assumed $\left(\mathrm{I}_{\mathrm{A}}\right)$ & 0.1227 & -0.0009 & - & 0.4181 \\
& REML $\left(\mathrm{I}_{\mathrm{R}}\right)$ & 0.0575 & 0.0012 & - & 0.3731 \\
\hline Y8 & Assumed $\left(\mathrm{I}_{\mathrm{A}}\right)$ & 0.1227 & -0.0009 & -0.0001 & 0.4180 \\
& REML $\left(\mathrm{I}_{\mathrm{R}}\right)$ & 0.1424 & -0.0008 & 0.0528 & 0.3535 \\
\hline
\end{tabular}


MUKAI, OYAMA, TSUJI and MIYATA

Table 5. Comparison of actual and expected selection responses for the traits in layer lines

\begin{tabular}{lcccc}
\hline \hline Lines/Traits & $\begin{array}{c}\text { Objective } \\
(\mathbf{q})\end{array}$ & $\begin{array}{c}\text { Expected } \\
\left(\mathbf{g}_{\mathrm{e}}\right)\end{array}$ & $\begin{array}{c}\text { Actual } \\
\left(\mathbf{g}_{\mathbf{a}}\right)\end{array}$ & $\begin{array}{c}\text { Theoretical } \\
(\mathbf{g})\end{array}$ \\
\hline E1 & & & & \\
EW(g) & 0.0 & -0.355 & -0.002 & -0.276 \\
BW(g) & 0.0 & -4.272 & $-12.015^{*}$ & -3.328 \\
SM(days) & - & -5.121 & $-1.917^{*}$ & -3.990 \\
EPA(\%) & - & 4.519 & $0.665^{*}$ & 3.521 \\
EPB(\%) & 5.0 & 4.604 & $0.952^{*}$ & 3.587 \\
L17 & & & & \\
EW(g) & 0.0 & 0.274 & -0.112 & 0.099 \\
BW(g) & 0.0 & -29.899 & $-32.079^{*}$ & -10.817 \\
SM(days) & - & -2.640 & 0.412 & -0.955 \\
EPA(\%) & - & 5.494 & $2.519^{*}$ & 1.988 \\
EPB(\%) & 5.0 & 5.632 & $1.806^{*}$ & 2.038 \\
Y 8 & & & & \\
EW(g) & 0.0 & -1.519 & 0.125 & -0.848 \\
BW(g) & 0.0 & -33.486 & -10.637 & -18.698 \\
SM(days) & -5.0 & -12.583 & $-3.107^{*}$ & -7.026 \\
EPA(\%) & - & 6.895 & $1.825^{*}$ & 3.850 \\
EPB(\%) & 5.0 & 8.752 & $1.760^{*}$ & 4.887 \\
\hline
\end{tabular}

See the text for meanings of $\mathbf{q}, \mathbf{g}_{\mathrm{e}}, \boldsymbol{g}_{\mathrm{a}}$, and $\boldsymbol{g}_{\mathrm{t}}$.

$* \mathrm{P}<0.05$.

consistent in direction with the objective. However, the amount of responses was less than theoretically expected and varied across lines because the degree of discrepancy in genetic parameters depended on lines. In this study, although assumed heritabilities agreed with REML estimates to a certain degree, but genetic and residual variance components were considerably different each other, especially in egg production efficiency. In addition, the disagreement found in genetic correlations affected on selection responses unfavorably not only in direction but also in amount. Of course, other important causes cannot be disregarded. For example, although the genetic variance and covariance structure is assumed to be kept constant, which means the same index can be applied during selection, genetic variances and covariances would change due to selection so that the optimum weighting coefficients of the index may change inevitably ${ }^{7,12)}$. It may affect adversely on the amount of responses attained. It is not clear how the deviation of changes found in one or more objective traits from pre-specified affects on an achievement of the other objective traits.

These results indicate that in order to attain pre-specified breeding objective more reliable variance and covariance estimates for a line under question should be used for constructing the index. In poultry breeding, analysis of variance under hierarchical family structure has been used to estimate variance components, however REML under an animal model has good properties in estimation and nowadays can be easily applied on such a very large mixed model equations constructed in poultry population. It is well known, however, that reliability of REML estimates depends on data structure of a given population and possible analytical model applied. Especially, in REML, pedigree information is essential so 


\section{Selection Responses in Layer Lines}

that REML is applicable at least after second generation. Robertson ${ }^{11}$ suggested that selecting $50 \%$ resulted in a maximum total response but not rate of progress. Accordingly, at the beginning of selection, in case of no reliable genetic parameters the selection should not be intense. Further study is necessary to evaluate the effect of discrepancy of estimated parameters from true on selection responses attained by selection index for desired gains.

\section{References}

1) Danbaro G, Oyama K, Mukai F, Tsuji S, Miyata T. Estimation of genetic parameters by restricted maximum likelihood under multitrait animal models in selected layer lines. Jpn. Poultry Sci., 33 : 185-192. 1996.

2) Hazel LN. The genetic basis for constructing selection indexes. Genetics, 28 : 476-490. 1943.

3) Henderson CR. Applications of linear models in animal breeding. University Guelph Press. Guelph, Canada. 1984.

4) Itoh $Y, Y$ amada $Y$. Selection indices for desired relative genetic gains with inequality constraints. Theor. Appl. Genet., $75: 731-735.1988$.

5) Itoh $Y, Y a m i a d a ~ Y$. Linear selection indices for non-linear profit functions. Theor. Appl. Genet., 75 : 553-560. 1988.

6) Kempthorne O, Nordskog AW. Restricted selection indices. Biometrics, $15:$ 10-19. 1959.
7) McMillan I, Fairfull RW, Friars GW, Quinton $M$. The effect of simultaneous selection on the genetic correlation. Theor. Appl. Genet., 91 : 776-779. 1995

8) Moav R, Hill WG. Specialized sire and dam lines. IV. Selection within lines. Anim. Prod. 8: 373-390. 1966.

9) Patterson HD, Thompson R. Recovery of inter -block information when block sizes are unequal. Biometrika, 58 : 545-554. 1971.

10) Pesek J, Baker RJ. Desired improvement in relation to selection indices. Can. J. Plant Sci,, $49: 803-804.1969$.

11) Robertson A. A theory of limits in artificial selection. Proc. Roy. Soc. London, B., 153 : 234249. 1960.

12) Robertson A. The effect of selection on the estimation of genetic parameters. $Z$. Tierzüchtg. Züchtgsbiol., 94 : 131-135. 1977.

13) Sorensen DA, Kennedy BW. Analysis of selection experiments using mixed model methodology. J. Anim. Sci., 63 : 245-258. 1986.

14) Sorensen DA, Kennedy BW. Estimation of genetic variances from unselected and selected population. J. Anim. Sci., 59 : 1213-1223. 1984.

15) Wilton JW, Evans DA, Van Vleck LD. Selection indices for quadratic models of total merit. Biometrics, 24 : 937-949. 1968.

16) Yamada $Y$, Yokouchi $K$, Nishida A. Selection index when genetic gains of individual traits are primary concern. Jpn. J. Genet., $50: 33-41$. 1975 . 


\title{
卵用鶏における改良目標に基づく選抜指数式による実現ならびに 期待選抜反応の比較
}

\author{
向井文雄・大山憲二1) \\ 神戸大学農学部, 神戸市灘区 657 \\ 1) 神戸大学大学院自然科学研究科, 神戸市灘区 657 \\ 2) 家畜改良センター岡崎牧場, 岡崎市 444-21
}

\begin{abstract}
家畜改良センタ一岡崎牧場において改良量に基づく選拔指数式により 1989 午加ら 1994 年にかけて選 拔加実施されてきた卵用鵎 3 系統を用いて, 期待される選抜反応と実際に達成された選抜反応之の比較



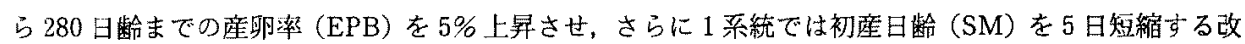
良目標が設定された，選抜指標としては，EW，BW，SM 掞よで169 日秢から280日踴の産卵率（EPA） が用いられた，選抜指数式の作成には 3 系統と屯に同一の遣伝的パラメータ一が仮定され，同一の指数 により 5 世代にわだる選抜が夹施された，達成された選抜反応は，多形質 REML 法により推定した遭 伝的パラメーターをもとに，多形質アニマルモデル BLUP 法を用いて育種価を予测し，生年ごとの育種 洒予測值平均の世代への回帰係数上り算出した. 3 系統と6に, BW を除き, 選抜反庍の方向は設定した 改良目標と一致していた，しかし，体重の選抜反応は 2 系統では有意な減少煩向を示し，これは BW と EPA あるいはEPB間には遗伝的関連がない之仮定した指数を用いているのに対して, REMLでは小さ いながらも負の遺伝相関が存在したことに起因すると考えられた。 EPBの改良量に関しては，仮定した パラメーターと各系統の REML 推定値の羑異を反映して，ほぼ理諭值に一致する系統から $30 \%$ 程度の 系統までと巽なる反応量を示した．したがって，REML 法による各系統固有の遗伝的パラメーター推定 値を用いた選抜指数式による選抜が改良の方向性や改良量に関して確実な効果をもたらすものと考元ら れた.
\end{abstract}

